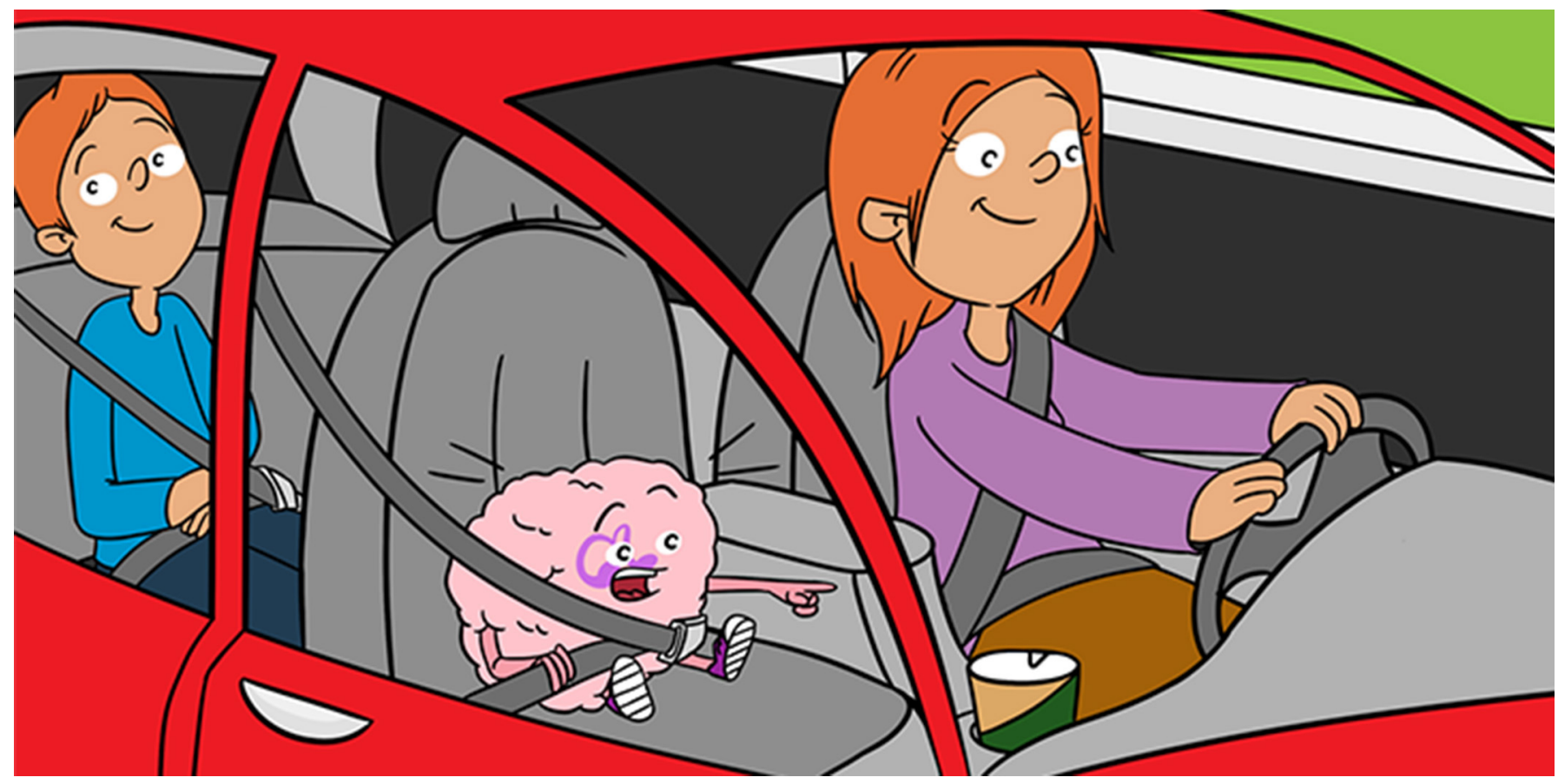

\title{
HOW DOES THE BRAIN KNOW WHERE WE ARE?
}

\section{Dori Derdikman *}

Rappaport Faculty of Medicine and Research Institute, Technion, Haifa, Israel

YOUNG REVIEWERS:

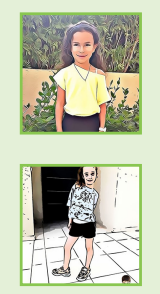

AYALA

AGE: 8

REUT

AGE: 8
In our brains, as in the brains of other mammals, such as monkeys and mice, there is an area called the hippocampus, which allows us to find our way and not get lost. Sometimes we want to drive to a certain place but end up in a different place. How does that happen? What exactly is a "place?" Do we have a sense of "place" like we have other senses-sight, hearing and smell? In this paper, we will talk about "place cells" and other types of brain cells that we investigate in the lab, which give our brains an internal map function and act as a natural "Waze" navigation system in each of us, to help us find our way between different places.

\section{THE BRAIN FIGHTS WITH ITSELF}

Last week, I got into the car with my wife Ruthi to give her a ride to work (Figure 1). I started driving and we chat along the way. Ruthi's work is in Haifa, Israel, in a neighborhood called Hadar, and my work is in a neighborhood called Bat Galim, near the sea. We live on Mount Carmel, so I started driving down the mountainside, on the usual road I always take. After a few minutes, we noticed that the car accidently 
Figure 1

Illustration: Shira Derdikman.

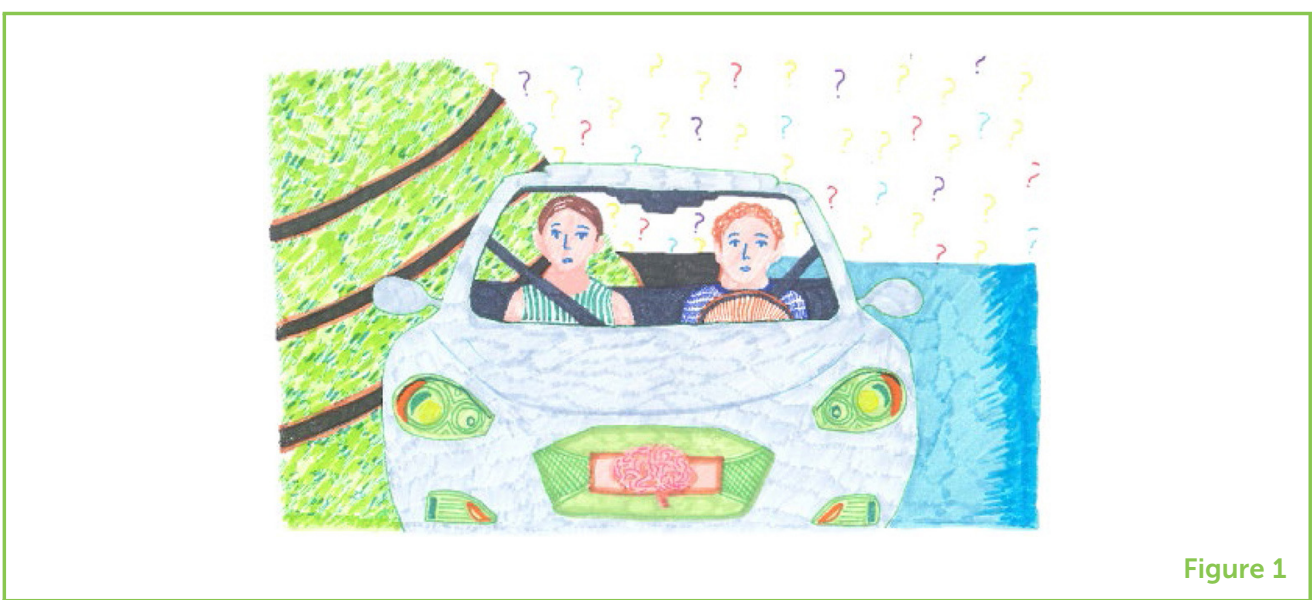

"took" us to my work, instead of Ruthi's work. Of course, we corrected the route immediately, but this extra turn cost us an additional half hour in heavy traffic. What happened there exactly? How did it turn out, that I planned to arrive at one place (Ruthi's work) but instead arrived at another place (my work) without noticing it?

It turns out that, in our brains, there are different parts responsible for the question "where should I go?" and sometimes these brain areas give us different answers to this question. When I got into the car, one brain area told me, "Drive the way you go every morning, to the place you always drive to," while another area said, "Wait, wait, wait! Today you need to deviate from your habit and navigate to a new place." The problem is that sometimes the brain area that is responsible for the habit takes over, and makes us drive somewhere we did not intend to drive to.

The Israeli professor Daniel Kahneman, who won a Nobel prize in economics, claimed that the brain has two systems, called system 1 and system 2. System 1 works faster and automatically, while system 2 works slower and demands concentration in order to operate, but allows us to accomplish more complicated tasks. System 2 needs our conscious attention, while we notice less what system 1 does, since it tends to keep operating even when are not paying attention to it. In the case of our car ride, I needed to drive Ruthi to work, which made me deviate from my habit. In order to arrive at the right destination, I had to make system 2 deal with the navigation-but system 2 was busy talking with Ruthi, so system 1 took over the navigation and we found ourselves on the way to my work instead of Ruthi's work, out of habit.

\section{THE INTERNAL MAP INSIDE OUR BRAIN}

In my lab, I study the role of brain system 2 in the process of navigation. System 2 is a flexible system that allows us to find our 
Figure 2

(A) Hippocampus means "seahorse" in Greek, because the shape of this brain area is similar to the shape of a seahorse (illustration: Shira Derdikman). (B) Position of hippocampus in the human brain (source: Wikipedia).

\section{HIPPOCAMPUS}

A brain region known to be related to memory and navigation.

\section{NEURON}

A nerve cell in the brain.
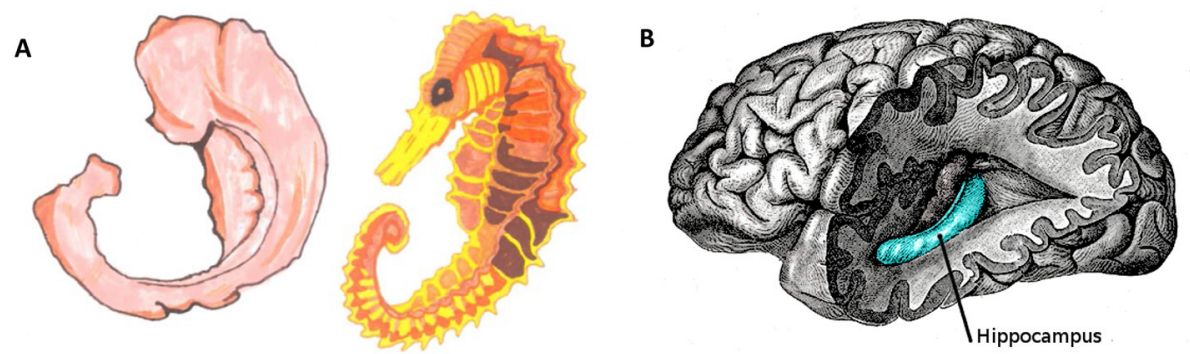

Figure 2

way around places we have not been before. Imagine that we each have a small map that is stored inside our brains. What is this map? What does it allow us to do? In the human brain, there is an area called the hippocampus (Figure 2), which we believe is part of system 2. The hippocampus contains the brain areas that are responsible for navigation in less familiar places. The hippocampus in humans, monkeys, and mice performs this same navigation function. All these animals need to find their way from one place to another, so it is not surprising that they have brain areas responsible for that task. The fact that the hippocampus exists in humans as well as in other mammals, such as mice, supports the claim that all mammals shared a common ancestor, who lived millions of years ago and also had a hippocampus.

In my lab at the Technion, I study the hippocampus of mice. In mice, as in humans, the hippocampus is involved in the calculations responsible for navigation. Mice do not need to navigate from home to work, like I do. But they do need to know how to navigate from their den to our kitchen in order to find cheese crumbles on the floor, and to then return safely to their den (without bumping into my cat on the way). The hippocampus contains millions of brain cells (called neurons), which are the cells that are responsible for transmitting signals from one place in the brain to another, using electrical currents. This is why brain cells are very long and look a bit like tiny communication cables (Figure 3 ). In the lab, we record electrical activity from these neurons.

\section{PLACE CELLS AND OTHER CELLS}

A big breakthrough in the study of the hippocampus occurred almost 50 years ago, in 1971. Prof. John O'Keefe, from London, and his Israeli student Dr. Jonathan Dostrovsky, discovered very special brain cells in the hippocampus of a rat. Prof. O'Keefe discovered that these special cells in the hippocampus respond (meaning send an electrical signal to other cells) when the rat is present in a specific location. However, when the rat is in another location, these cells are quiet and are not electrically active. So, when the researchers recorded the 
Figure 3

Brain cell. One brain cell, also called a neuron, can be very narrow, about one hundredth of a millimeter, but can be very long, in order to transmit information from one place to another in the brain, using electrical currents (illustration: Shira Derdikman).

\section{PLACE CELL}

A nerve cell in the hippocampus, active when the animal is at a certain place.

\section{GRID CELL}

A nerve cell near the hippocampus, that is active when the animal passes through certain points which form the shape of hexagons.

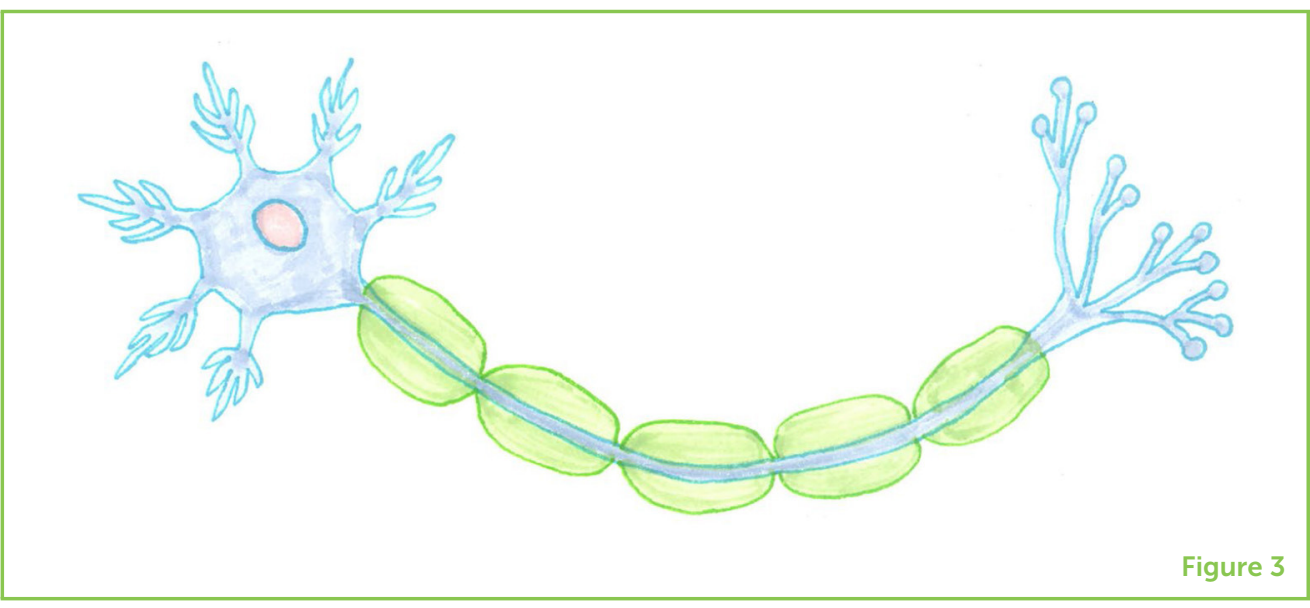

activity of these cells in the hippocampus, they could know something about where the rat was located at that moment (Figure 4). O'Keefe suggested that these cells form some sort of an internal map inside the rat's brain (or human, or monkey), which helps it to know where it is and how to find its way. This map is sort of like an internal "Waze" navigation system, which exists in all mammals and helps them to find their way from one place to another.

Initially, scientists were very skeptical about O'Keefe's findings, since the idea of place cells sounds very strange. How could there be brain cells that start working when we are in a certain location? Up until O'Keefe's discovery, scientists believed that brain cells in animals were mostly occupied by two things: sensing (sight, hearing, touch, smell, and taste) and movement. It was known at that time that there are brain cells that respond to what our five senses encounter, but "place" is something far less defined. What does it mean that the cells respond to a certain "place?" How can a place be defined? This is not a simple question whatsoever, but, almost 50 years later, there have been so many experiments that support the existence of place cells that it is hard to object to them. In 2014, John O'Keefe received the recognition he deserved for this important discovery when he won a Nobel Prize in medicine for the discovery of place cells.

Since the discovery of place cells in the 1970's, many other types of brain cells dealing with navigation have been discovered. Another important type of navigation cells, called grid cells, were discovered in 2005 in a lab in Norway by Profs. Edvard and May-Britt Moser (along with their students). Their discovery was also awarded a Nobel Prize. The Mosers discovered that a brain region near the hippocampus contains brain cells that create a spatial map that works with hexagons as its base. This is a bit like saying that the brain maps the world using squares on a paper, only instead of squares there are hexagons. These hexagons resemble other places in nature where there are hexagons, such as a beehive (Figure 5). This discovery excited me so much that, 
Figure 4

Place cells are brain cells in the

hippocampus that "wake up" and start sending electrical signals each time the animal passes through a certain location in the box. In this example, a place cell "wakes up" when the rat passes through the area marked by the yellow circle. Another place cell will "wake up" at another location in the box. These cells are found in the hippocampus of other mammals, too.

\section{Figure 5}

The functioning of a grid cell resembles the shape of a beehive. Inside a square box area (right), grid cells send electrical currents each time the animal passes through one of the locations marked with "x." The active locations are arranged in shapes of hexagons, like cells in a beehive (left). One example of a hexagon is marked with a red line on the right (image: David Hablützel from Pixabay).
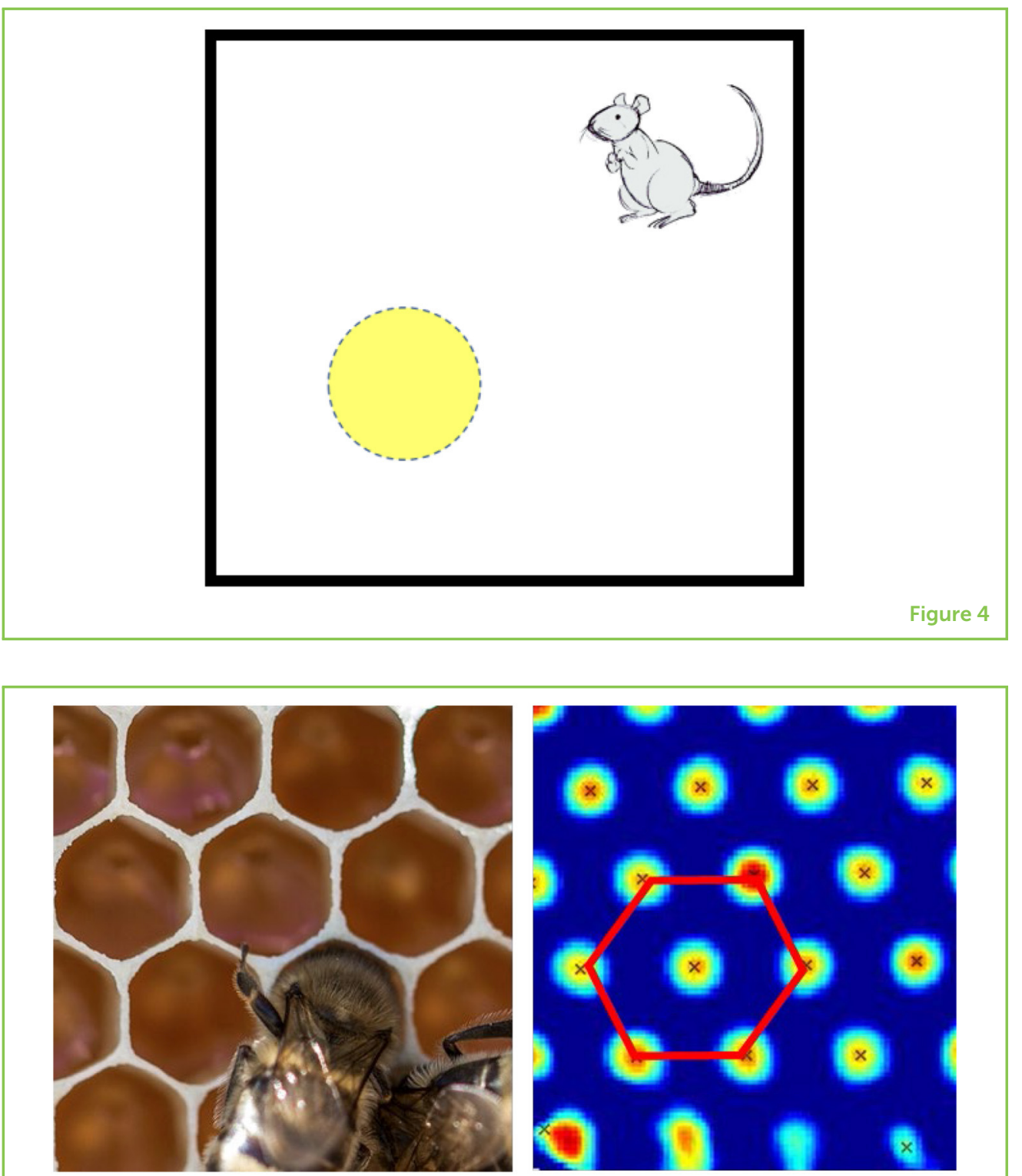

Figure 5

in 2006, I traveled to the Moser lab in Norway and worked with them on studying grid cells, which had just been discovered.

\section{A PEEK INTO THE FUTURE}

What does the future hold? Now that different types of cells working together as the brain's internal map have been discovered, one of the central goals of this research is finding out how these cells operate, meaning how they identify what a "place" is. In my lab, we have found that certain locations are more important than others, and we study how the brain decides what is important and what is not. Additionally, we study the pathway in the brain that transmits information from the senses (sight and touch) to the internal map. The technology behind brain studies has advanced enormously in the last 50 years. 
While O'Keefe was able to record electrical activity only from single brain cells, today we can record hundreds and thousands of brain cells simultaneously. This brings us to a new era of Big Data, in which we can record millions of signals from the brain. The big challenge now becomes deciphering all these signals in order to answer the basic question we started with-how does the brain know where we are?

\section{ACKNOWLEDGMENTS}

Thanks to Itamar Derdikman, Ruth Derdikman-Eiron, and the young reviewers who read the text, edited it, and commented. Thanks to Shira Derdikman for the illustrations.

SUBMITTED: 18 February 2020; ACCEPTED: 31 March 2020;

PUBLISHED ONLINE: 08 May 2020.

EDITED BY: Idan Segev, Hebrew University of Jerusalem, Israel

CITATION: Derdikman D (2020) How Does the Brain Know Where We Are? Front. Young Minds 8:59. doi: 10.3389/frym.2020.00059

CONFLICT OF INTEREST: The author declares that the research was conducted in the absence of any commercial or financial relationships that could be construed as a potential conflict of interest.

COPYRIGHT @ 2020 Derdikman. This is an open-access article distributed under the terms of the Creative Commons Attribution License (CC BY). The use, distribution or reproduction in other forums is permitted, provided the original author(s) and the copyright owner(s) are credited and that the original publication in this journal is cited, in accordance with accepted academic practice. No use, distribution or reproduction is permitted which does not comply with these terms.

\section{YOUNG REVIEWERS}

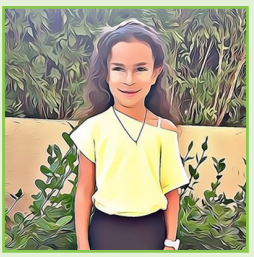

AYALA, AGE: 8

I love to dance different styles-ballet, hip hop, modern, and jazz. I enjoy to create, read, write, and even solve math problems. I have cats, love all the animals including ants. Likes to play the piano and it is very important for me to spend time with my friends.

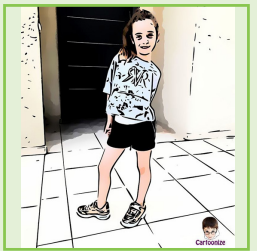

\section{REUT, AGE: 8}

Reut's interests include sports and science. She practices Karate in the last 2 years and is enthusiastic about Hip Hop dancing. 


\section{AUTHOR}

\section{DORI DERDIKMAN}

Prof. Dori Derdikman is a brain researcher in the Rappaport Faculty of Medicine at the Technion. His lab studies behavior, learning, and memory in the brain, mostly with respect to spatial memory of places. In his lab there are seven students working toward advanced degrees (Masters and Ph.D.) studying different aspects of the subject. *derdik@technion.ac.il 